American Journal of Agricultural and Biological Science 2(2): 118-122, 2007

ISSN 1557-4989

(C) 2007 Science Publications

\title{
Effect of Organic and Inorganic Fertilizers on Nitrogen and Potassium Uptake and Yield of Sweet Corn Grown on an Acid Soil
}

\author{
Mohd. Taufik Mohd. Yusuff, Osumanu Haruna Ahmed, Wan Asrina Wan Yahaya and \\ Nik Muhamad Ab. Majid \\ Department of Crop Science, Faculty of Agriculture and Food Sciences, \\ Universiti Putra Malaysia Bintulu Campus, Sarawak \\ 97008 Bintulu, Sarawak Malaysia
}

\begin{abstract}
A field study was carried with the following objectives: (i) To investigate the effect of compost, $\mathrm{N}$, and $\mathrm{K}$ fertilizers on selected chemical properties of Bekenu series (Tipik Tualemkuts), and (ii) To investigate the effect of compost, $\mathrm{N}$ and $\mathrm{K}$ fertilizers on $\mathrm{N}$ and $\mathrm{K}$ uptake and yield of Masmadu variety cultivated on Bekenu series. Treatments evaluated were: (i) No fertilization (T1), (ii) Hundred percent inorganic fertilizer application (T2), (iii) Eighty percent of N fertilizer plus twenty percent of N from compost application (T3), (iv) Sixty percent of N fertilizer plus forty percent of N from compost (T4), and (v) Application of hundred percent compost (T5). The experiment was conducted at the share farm of Universiti Putra Malaysia Bintulu Campus, Sarawak, Malaysia. The experimental design was a randomized complete block design (RCBD) with 4 replications. Nitrogen and $\mathrm{K}$ were applied in the forms of urea $(46 \% \mathrm{~N})$ and muriate of potash $\left(60 \% \mathrm{~K}_{2} \mathrm{O}\right)$ in split i.e., at 15 days after planting (DAP) and 36 DAP, respectively. At 73 DAP, plants were harvested. The fresh weight of cobs excluding guard rows was recorded. Dry weight (stem and leaves), $\mathrm{N}, \mathrm{K}, \mathrm{Ca}$, and $\mathrm{Mg}$ concentrations were determined by standard procedures. Soil sampling was done before and after fertilization. Soil total $\mathrm{N}$ was determined using the Kjeldahl method while exchangeable $\mathrm{K}, \mathrm{Ca}$, and $\mathrm{Mg}$ were extracted using the double acid method and their concentrations determined using atomic absorption spectrophotometry. Dry ashing method was used for the determination of $\mathrm{K}, \mathrm{Ca}$, and $\mathrm{Mg}$ concentrations in plant tissues while the Kjeldahl method was used to determine total $\mathrm{N}$ in plant tissues. The concentrations multiplied by the oven dried weight of roots and stem provided $\mathrm{N}, \mathrm{K}, \mathrm{Ca}$ and Mg uptake in these plant parts. T2, T3, T4 and T5 affected soil bulk density, CEC, pH, total N, exchangeable $\mathrm{K}, \mathrm{Ca}$ and $\mathrm{Mg}$. The dry weight of Masmadu leaf was not affected by fertilization and so was $\mathrm{N}$ and $\mathrm{K}$ uptake in this plant part. $\mathrm{T} 2$ was superior to the other treatments in terms of stem dry weight and cob production although the uptake of $\mathrm{N}$ and $\mathrm{K}$ in Masmadu stem under T2 was statistically not different from $\mathrm{T} 3$, and $\mathrm{T} 4$. Isotopic studies to quantify the amount of $\mathrm{N}$ and $\mathrm{K}$ contributed by compost in relation $\mathrm{N}$ and $\mathrm{K}$ uptake and yield may help to conclusively explain why $\mathrm{T} 2$ was superior to $\mathrm{T} 3$ and $\mathrm{T} 4$ in particular.
\end{abstract}

Keywords: Bekenu series, sweet corn, organic fertilizers, inorganic fertilizers, compost, Malaysia

\section{INTRODUCTION}

The acceptance of crop produce can be influenced by the source of nutrients involved in its production ${ }^{[1]}$. Generally, in developing countries, a $\mathrm{kg}$ of vegetable or crop produce using organic fertilizers attracts premium than the same quality produced using inorganic fertilizers. This is because it is believed that the former is devoid of synthetic chemicals. The organic matter produced during composting can beneficially add to soil to supply nutrient such as $\mathrm{N}, \mathrm{P}, \mathrm{K}$ and essential micronutrients to crop $^{[2]}$. In most studies, compost application has been observed to have positive effect on soil physical and biological properties. The high rate of compost application however cannot be done because when the application is greatly in excesses of crop needs, it becomes undesirable since the nutrients may not be used effectively and the risk of water and soil

Corresponding Author: $\quad$ Osumanu Haruna Ahmed, Department of Crop Science, Faculty of Agriculture and Food Sciences, Universiti Putra Malaysia Bintulu Campus, Sarawak, Malaysia, Tel: (+6086855406, Fax: $+608685415$ 
pollution is high $^{[3]}$. Thus the integrated nutrient management by complementary use of chemical fertilizer and compost seems to be the best way to solve this problem. In this study, it was expected that the right proportion of chemical fertilizer and compost may improve corn yield on Berkenu series (Tipik Tualemkuts) by improving the fertility status of the soil. Bekenu series is a member of the Bekenu family which is fine loamy, siliceous, isohypherthermic, red yellow to yellow Tipik Tualemkuts ${ }^{[4]}$. It is characterized by being deep, well drained profile with brownish yellow to yellow subsoil color. The series has low fertility status but can be good for crops such as corn if fertilized and properly managed.

Sweet corn is among the popular cereals widely cultivated in Malaysia. In 2001, the hectarage of sweet corn in Malaysia was 10,662 ha out of which 5,763 ha was in Sabah and Sarawak ${ }^{[5]}$. Sweet corn offers a stable market in Malaysia as it is one of the important cereals ${ }^{[6]}$ and the commonly grown variety in this country is Masmadu. This sweet corn variety was produced by Malaysia Agriculture Research Development Institute (MARDI) in 1990 and it was the cross bred sweet corn from Honey Jean and Across 7824 variety. Masmadu variety produces about 30,000 cob per ha. Although nutrient uptake of sweet corn seems to depend on soil fertility (e.g. $\mathrm{N}$ and $\mathrm{K}$ deficiency limits maize production) this aspect has not been investigated on Bekenu series. The objectives of this study were: (i) To investigate the effect of compost, $\mathrm{N}$, and $\mathrm{K}$ fertilizers on selected chemical properties of Bekenu series, and (ii) To investigate the effect of compost, $\mathrm{N}$, and $\mathrm{K}$ fertilizers on $\mathrm{N}$ and $\mathrm{K}$ uptake and yield of Masmadu variety grown on Bekenu series.

\section{MATERIALS AND METHODS}

This study was conducted at the share farm of Universiti Putra Malaysia Bintulu Campus (UPMKB), Sarawak on Bekenu soil series. Treatments evaluated were: (i) No fertilization (T1), (ii) Hundred percent inorganic fertilizer application (T2), (iii) Eighty percent of $\mathrm{N}$ fertilizer plus twenty percent of $\mathrm{N}$ from compost application (T3), (iv) Sixty percent of $\mathrm{N}$ fertilizer plus forty percent of $\mathrm{N}$ from compost (T4), and (v) Application of hundred percent compost (T5).

The compost used in this studied was produced from a mixture of chicken dung and saw dust by UPMKB. The compost was analyzed before field application to ensure the right amounts of $\mathrm{N}$ and $\mathrm{K}$ as specified in T3, T4 and T5 were applied. The chemical analyses conducted were: (i) Kjedhal method ${ }^{[7]}$ to determined total $\mathrm{N}$, (ii) Leaching $\operatorname{method}^{[8]}$ to determined cation exchange capacity (CEC), and (iii) Dry Ashing method ${ }^{[9]}$ to extract $\mathrm{K}$ and the $\mathrm{K}$ determined by Atomic absorption spectrophometry (AAS).

The experimental site was cleared, ploughed and rotovated after which $2 \mathrm{~m}$ x $2.5 \mathrm{~m}$ plots were set up. The experimental design was a randomized complete block design with 4 replications. The compost was applied to the plots assigned T3, T4 and T5 and a week after, Masmadu seeds were planted at a rate of 4 seeds per hole in of all the experimental plots. The planting distance was $25 \mathrm{~cm}$ within plants and $75 \mathrm{~cm}$ between rows. Seven days after planting, plants were thinned to 1 plant to ensure good growth. Urea $(46 \% \mathrm{~N})$, China rock phosphate $\left(36 \% \mathrm{P}_{2} \mathrm{O}_{5}\right)$, and Muriate of potash $(60$ $\% \mathrm{~K}_{2} \mathrm{O}$ ) were applied in split i.e., at 15 and 36 days after planting (DAP) respectively to the plots assigned T2, T3, and T4. The compost, N, K, and P used per plot are summarized in Table 1. Soil samples were taken before planting and $72 \mathrm{DAP}$ at a depth of 0 to $20 \mathrm{~cm}$ using soil auger. The soil was air dried, and sieved to pass $2 \mathrm{~mm}$ sieve. Soil exchangeable $\mathrm{K}, \mathrm{Ca}, \mathrm{Mg}$, and $\mathrm{Na}$ were extracted using the double acid method ${ }^{[8]}$. Atomic absorption spectrophometry was used to determine these cations. Total $\mathrm{N}$ was determined using microKjedhal method ${ }^{[7] .}$ The ammonium acetate (leaching) method $^{[8]}$ was used to determine cation exchange capacity (CEC) of the soil. The soil $\mathrm{pH}$ in water and 1 $\mathrm{N} \mathrm{KCl}$ was analyzed using a digital $\mathrm{pH}$ meter. The coring method was used to determine the bulk density of the soil

At 73 DAP, the Masmadu cobs were harvested (excluding guard rows) and their fresh weight determined. The tops of the plants were also harvested and partitioned into stem and leaves. These parts were oven dried until constant weight was attained and weight determined using a digital balance. Total $\mathrm{N}$ of the plant tissues was determined by the micro-kjeldhal $\operatorname{method}^{[7]}$. The dry ashing method was also used ${ }^{[9]}$ to extract total $\mathrm{K}, \mathrm{Ca}, \mathrm{Mg}$, and $\mathrm{Na}$ of the plant parts after which AAS was used to determine these cations.

Analysis of variance (ANOVA) was used to detect treatment effect, while treatment means were compared by Tukey test at $\mathrm{P} \leq 0.05$ using the Statistical Analysis System version $9.1^{[10]}$.

\section{RESULTS AND DISCUSSION}

The CEC and $\mathrm{Ca}$ of the compost used in this study were relatively high while total $\mathrm{N}$ and $\mathrm{Mg}$ were relatively 
low (Table 2). The low $\mathrm{N}$ may be because the compost was produced from a mixture of chicken dung and sawdust.

Table 1: Amounts of compost, N, P, and K applied per plot

\begin{tabular}{ccccc}
\hline Treatment & $\begin{array}{l}\text { Compost } \\
(\mathrm{kg})\end{array}$ & $\begin{array}{l}\text { Urea } \\
(\mathrm{g})\end{array}$ & $\begin{array}{l}\text { MOP } \\
(\mathrm{g})\end{array}$ & $\begin{array}{l}\text { China } \\
\text { rock } \\
\text { phosphate } \\
(\mathrm{g})\end{array}$ \\
\hline T1 & 0.0 & 0 & 0 & 0 \\
T2 & 0.0 & 130 & 167 & 386 \\
T3 & 0.5 & 104 & 165 & 386 \\
T4 & 1.0 & 78 & 164 & 386 \\
T5 & 2.4 & 0 & 0 & 0 \\
\hline
\end{tabular}

Table 2: Chemical properties of compost

\begin{tabular}{lcccc}
$\begin{array}{l}\text { CEC } \\
(+) / \mathrm{kg} \text { soil })\end{array}$ & $\mathrm{N}$ & $\mathrm{K}$ & $\mathrm{Ca}$ & $\mathrm{Mg}$ \\
& & $\%$ & & \\
\hline 24.50 & 2.50 & 0.91 & 38.50 & 2.07 \\
\hline
\end{tabular}

Table 3: Physical and chemical properties of Bekenu series before planting

$\begin{array}{llllllll}\begin{array}{l}\mathrm{BD} \\ \left(\mathrm{g} / \mathrm{cm}^{3}\right)\end{array} & \mathrm{pH}_{\mathrm{w}} & \mathrm{pH}_{\mathrm{KCl}} & \mathrm{CEC} & \begin{array}{c}\mathrm{N} \\ (\%)\end{array} & \mathrm{K} & \mathrm{Ca} & \mathrm{Mg} \\ \mathrm{mg} / \mathrm{kg} & & \end{array}$

\begin{tabular}{llllllll}
\hline 1.6 & 4.3 & 4.0 & 12.3 & 0.3 & 5.5 & 1.9 & 43.6 \\
\hline
\end{tabular}

$\mathrm{BD}=$ bulk density; $\mathrm{pH}_{\mathrm{w}}$ and $\mathrm{pH}_{\mathrm{KCl}}=\mathrm{pH}$ in water and $\mathrm{KCl}$ respectively; $\mathrm{CEC}$ is in $\mathrm{cmol}(+) / \mathrm{kg}$ soil

Table 6: Effect of treatment on fresh yield (cob) of Masmadu variety

Treatment

$\begin{array}{ll}\text { T1 } & 0.20^{\mathrm{a}} \\ \text { T2 } & 3.00^{\mathrm{b}} \\ \text { T3 } & 0.97^{\mathrm{c}} \\ \text { T4 } & 1.43^{\mathrm{c}} \\ \text { T5 } & 0.40^{\mathrm{a}}\end{array}$

Note: Means with different alphabets indicate significant difference between treatments by Tukey's test at $\mathrm{P} \leq 0.05$.

The selected chemical and physical characteristics of Bekenu series before planting are presented in Table 3. The bulk density, $\mathrm{pH}, \mathrm{CEC}$, total $\mathrm{N}$ and exchangeable $\mathrm{K}, \mathrm{Mg}$ and $\mathrm{Ca}$, were typical of Bekenu series ${ }^{[4]}$ At harvest, the bulk density, $\mathrm{CEC}, \mathrm{pH}$ (water and $\mathrm{KCl}$ ), total $\mathrm{N}$ and exchangeable $\mathrm{Ca}$ of Bekenu series were not significantly affected by the fertilization. Only exchangeable $\mathrm{K}$ and $\mathrm{Mg}$ of the soil were significantly affected by fertilization (Table 4).

Except for T2 whose effect on the dry weight of the stem of Masmadu was significantly higher than T1, the other treatments regardless of the plant part did not have significant effect (Table 5). The total $\mathrm{N}$ of the treatments was statistically similar but in the case of stem, except for T5, N (leaf) concentrations for T2, T3 and $\mathrm{T} 4$ were significantly higher than $\mathrm{T} 1$. The $\mathrm{K}$ concentration in the leaves of $\mathrm{T} 2$ was higher than those of $\mathrm{T} 1$ and $\mathrm{T} 5$ but in the case of stem, those of T2 and $\mathrm{T} 3$ were higher than $\mathrm{T} 1$ and T5. Generally, the Mg concentrations in the leaves irrespective of treatment were similar, and similar observation was true for stem.

Nitrogen and $\mathrm{K}$ fertilization had significant effect on $\mathrm{N}$ and $\mathrm{K}$ uptake in stem, but the opposite was true for their uptake in leaves (Table 5). For stem, $\mathrm{N}$ uptake under T2, T3, and T4 were significantly higher than T1 but for $\mathrm{K}$, only those of $\mathrm{T} 2$ and $\mathrm{T} 4$ were significantly higher than T1. Generally the $\mathrm{Ca}$ and $\mathrm{Mg}$ uptake in the leaves and stem of the fertilized plants compared to $\mathrm{T} 1$ were similar. In terms of cob production, T2 was superior to all of the other treatments (Table 6).

The insignificant differences between the bulk densities and CEC of the treatments including T1 (control) at harvest suggest that chemical fertilization as well compost application did not affect these soil characteristics within the time frame of this study (Table 4). This observation was not expected of T3, T4 and T5 because application of organic matter in the form of compost which usually has the ability of increasing soil bulk density and $\mathrm{CEC}^{[3]}$ did not reflect these treatments. It must however, be stressed that compost application usually improves soil bulk density and CEC upon several cropping cycles. The compost used in this study was also a mixture of chicken dung and sawdust but the bulk of this was made up of chicken dung. Because of the low $\mathrm{C} / \mathrm{N}$ ratio of chicken dung, the major part of the compost might have mineralized to release $\mathrm{N}, \mathrm{P}$, and $\mathrm{K}$ and only a part of it might have remained and was perhaps not sufficient to significantly improve the soil physical and chemical properties. Even though the application of compost may increase the soil $\mathrm{pH}$, a study has shown that the addition of $\mathrm{N}$ fertilizer on composts usage overcome this problem $^{[14]}$. 
Am. J. Agri. \& Biol., 2(2): 118-122, 2007

Table 4: Physical and chemical properties of Bekenu series after planting

\begin{tabular}{|c|c|c|c|c|c|c|c|c|}
\hline \multirow{3}{*}{$\begin{array}{c}\text { Treat } \\
\text { ments }\end{array}$} & \multirow{2}{*}{$\begin{array}{c}\text { Bulk } \\
\text { Density }\end{array}$} & \multirow{3}{*}{$\begin{array}{c}\text { CEC } \\
\text { Cmol(+ } \\
) / \mathrm{Kg} \\
\text { soil }\end{array}$} & \multicolumn{2}{|c|}{$\mathrm{pH}$} & \multirow{2}{*}{$\begin{array}{c}\text { Total } \\
\mathrm{N}\end{array}$} & \multicolumn{3}{|c|}{ Soil Exchangeable } \\
\hline & & & Water & $\mathrm{KCl}$ & & K & $\mathrm{Mg}$ & $\mathrm{Ca}$ \\
\hline & $\mathrm{g} / \mathrm{cm}^{3}$ & & & & $\%$ & & $\mathrm{mg} / \mathrm{kg}$ & \\
\hline $\mathrm{T} 1$ & $1.43^{\mathrm{a}}$ & $17.63^{\mathrm{a}}$ & $4.19^{\mathrm{a}}$ & $3.74^{\mathrm{a}}$ & $0.12^{\mathrm{a}}$ & $29.30^{\mathrm{b}}$ & $18.55^{\mathrm{b}}$ & $2.67^{\mathrm{a}}$ \\
\hline $\mathrm{T} 2$ & $1.38^{\mathrm{a}}$ & $19.08^{\mathrm{a}}$ & $4.36^{\mathrm{a}}$ & $3.73^{\mathrm{a}}$ & $0.13^{\mathrm{a}}$ & $32.70^{\mathrm{ab}}$ & $54.57^{\mathrm{a}}$ & $4.63^{\mathrm{a}}$ \\
\hline $\mathrm{T} 3$ & $1.43^{\mathrm{a}}$ & $18.98^{\mathrm{a}}$ & $4.41^{\mathrm{a}}$ & $3.76^{\mathrm{a}}$ & $0.14^{\mathrm{a}}$ & $39.21^{\mathrm{ab}}$ & $48.80^{\mathrm{a}}$ & $6.23^{\mathrm{a}}$ \\
\hline $\mathrm{T} 4$ & $1.48^{\mathrm{a}}$ & $17.96^{\mathrm{a}}$ & $4.38^{\mathrm{a}}$ & $3.76^{\mathrm{a}}$ & $0.15^{\mathrm{a}}$ & $44.17^{\mathrm{a}}$ & $51.27^{\mathrm{a}}$ & $6.77^{\mathrm{a}}$ \\
\hline T5 & $1.49^{\mathrm{a}}$ & $17.93^{\mathrm{a}}$ & $4.35^{\mathrm{a}}$ & $3.46^{\mathrm{a}}$ & $0.11^{\mathrm{a}}$ & $28.04^{\mathrm{ab}}$ & $20.51^{\mathrm{b}}$ & $5.23^{\mathrm{a}}$ \\
\hline
\end{tabular}

Note: Means with different alphabets in column indicate significant difference between treatments by Tukey's test at $\mathrm{P} \leq 0.05$.

The reason being that oxidation of $\mathrm{N}$ fertilizers, for example conversion of urea to ammonium ion produces $\mathrm{H}^{+}$that decreases the soil $\mathrm{pH}$ during reduction reaction. The $\mathrm{pH}$ in both water and $\mathrm{KCl}$ at harvest were typical of Bekenu series ${ }^{[4]}$ however, they were not affected by fertilization. This observation is consistent with the absence of significant increase soil total $\mathrm{N}$ regardless of treatment. Soil $\mathrm{pH}$ build up at soil microsites upon urea application is temporary and usually the effect is less than four weeks. In this study, soil samples were taken sixty five days after planting (harvesting time), hence the insignificant effect of fertilization on soil $\mathrm{pH}$ and total N, particularly for $\mathrm{T} 2(100 \%$ application of inorganic fertilizers such as urea). Certainly, T5 could not significantly increase the soil $\mathrm{pH}$ because compost improves soil fertility and in most cases it does not directly increase soil $\mathrm{pH}$ appreciably. Insignificant $\mathrm{N}$ accumulation in the plots treated with compost may be because of mineralization of the compost as previously discussed. The fact only the exchangeable K of T4 was significantly higher than $\mathrm{T} 1$ (control) and the exchangeable $\mathrm{K}$ of $\mathrm{T} 4$ not significantly different from $\mathrm{T} 2$, T3, and T5 suggests that the exchange properties such as CEC of fertilized plots were not sufficiently improved to hold more $\mathrm{K}$, although it cannot be ruled out that some of the $\mathrm{K}$ applied was taken up by the fertilized plants. The general lack of improvement in soil exchangeable $\mathrm{Mg}$ and $\mathrm{Ca}$ upon fertilization could be attributed to the low contents of these elements in the fertilizers (Table 5). Dilution effect ${ }^{[11,12]}$ may explain the general insignificant difference in the nutrient concentrations among treatments and this might have reflected in the insignificant dry weight of leaves and, $\mathrm{N}$ and $\mathrm{K}$ uptake in leaves upon fertilization. Although treatments T2, T3, and T4 had significantly increased $\mathrm{N}$ concentration and $\mathrm{N}$ uptake in stem, only stem dry weight and cob of $\mathrm{T} 2$ were significantly higher. Potassium uptake was also significantly higher for $\mathrm{T} 2$ than $\mathrm{T} 1$. These observations indicate that Masmadu responded quite well to inorganic fertilization than combinations of inorganic and organic fertilization or organic fertilization only. But this was contrary to the general notion that inorganic and organic fertilization is better than inorganic fertilization only. Probably, the contradiction here could be due to nutrient imbalance as T3, T4, and T5 were based on T2 (standard inorganic fertilization programme for Masmadu). Perhaps isotopic studies to quantify for instance the amount of $\mathrm{N}$ and $\mathrm{K}$ contributed by compost in relation $\mathrm{N}$ and $\mathrm{K}$ uptake and yield may shed more light on the findings of this work.

\section{CONCLUSIONS AND RECOMMENDATION}

Inorganic fertilization (T2) or combinations of inorganic and organic fertilization (T3 and $\mathrm{T} 4$ ) or organic fertilization (T5) only did not affect soil bulk density, $\mathrm{CEC}, \mathrm{pH}$, total $\mathrm{N}$, and exchangeable $\mathrm{Ca}$ but affected exchangeable $\mathrm{K}$ and $\mathrm{Mg}$. Dry weight of Masmadu leaf was not affected by fertilization and so was $\mathrm{N}$ and $\mathrm{K}$ uptake. Inorganic fertilization (T2) was superior in terms of stem dry weight and cob production although the uptake of $\mathrm{N}$ and $\mathrm{K}$ in Masmadu stem for T2 was similar to T3, and T4. Three or five cropping cycles may be required to confirm the findings in this study. In addition, further isotopic studies to quantify the amount of $\mathrm{N}$ and $\mathrm{K}$ contributed by compost in relation $\mathrm{N}$ and $\mathrm{K}$ uptake and yield may help to conclusively explain why T2 was superior to T3 and T4 in particular. 


\section{REFERENCES}

1. Arthur, W., 1994. Reason why organic growers do not use synthetic compounds fertilizers. Commun. Soil Sci. Plant Analy., 8: 125-128

2. Jacobsen, S. T., 1995. Aerobic decomposition of organic waste. 2: Value of compost as fertilizer. Resource Conservation Recy., 15-31.

3. Prabhat K. Gupta. 1999. A handbook of soil, fertilizer and manure. Agrobios India, pp: 269-329.

4. Paramanathan S., 2000. Soils of Malaysia: Their characteristics and identification. Volume 1. Akademi Sains Malaysia, Kuala Lumpur, pp: 121384.

5. Anon., 2000a. Statistic on commodities 2002. Ministry of Primary Industries, Malaysia, pp: 4050

6. Wong, C. and J. Abd. Munir, 1993. Soil chemical characteristics of vegetables plots at Cameron Highlands. MARDI Report, 170: 9-10
7. Bremner, J. M., 1965. Total nitrogen. American Society of Agronomy Monograph 9: 1149-1178.

8. Cottenie, A., 1980. Soil testing and plant testing as a basis of fertilizer recommendation. FAO Soils Bulletin, 38: 70-73.

9. Kim H. Tan., 1996. Soil sampling, preparation, and analysis. Marcel Dekker, Inc., New York, pp: 170174.

10. SAS 2007. SAS Enterprise Guide. SAS Institute Inc, pp: 3-15.

11. Marschner, H. 1995. Mineral nutrition of higher plants (2nd edition). Academic Press, London, pp: 483-507.

12. Mengel, K. and E. A. Kirkby, 1996. Principles of plant nutrition (4th edition). Panina Publishing Corporation, New Delhi, pp: 147-149. 